Article

\title{
Research on Improving Concrete Durability by Biomineralization Technology
}

\author{
How-Ji Chen ${ }^{1}$, Ming-Cheng Chen ${ }^{1}$ and Chao-Wei Tang ${ }^{2,3,4, *}$ \\ 1 Department of Civil Engineering, National Chung-Hsing University, No. 250, Kuo Kuang Road, \\ Taichung 40227, Taiwan; hojichen@dragon.nchu.edu.tw (H.-J.C.); eric.panyu@gmail.com (M.-C.C.) \\ 2 Department of Civil Engineering \& Geomatics, Cheng Shiu University, No. 840, Chengching Rd., Niaosong \\ District, Kaohsiung 83347, Taiwan \\ 3 Center for Environmental Toxin and Emerging-Contaminant Research, Cheng Shiu University, No. 840, \\ Chengching Rd., Niaosong District, Kaohsiung 83347, Taiwan \\ 4 Super Micro Mass Research \& Technology Center, Cheng Shiu University, No. 840, Chengching Rd., \\ Niaosong District, Kaohsiung 83347, Taiwan \\ * Correspondence: tangcw@gcloud.csu.edu.tw; Tel.: +886-7-735-8800
}

Received: 20 January 2020; Accepted: 7 February 2020; Published: 9 February 2020

\begin{abstract}
The interfacial transition zone (ITZ) around aggregates in concrete is a weak area with higher porosity than the matrix; it breaks easily under stress and is not conducive to the durability of concrete. However, the ITZ in concrete is full of calcium hydroxide crystals, which can provide the calcium source required for biomineralization. In view of this, this study aims to use the biological activity (i.e., biomineralization technology) existing in nature to enhance the ITZ in concrete and repair concrete cracks to improve the strength and durability of concrete. In this study, the bacterial strain Sporosarcina pasteurii, which is environmentally friendly, was selected. In addition, lightweight aggregate was used as a bacterial carrier. The bacteria were first sporulated. To protect the strains, the biological species were fixed in porous lightweight aggregates. These lightweight aggregates were then used as concrete aggregates. The planned tests included concrete engineering properties (i.e., compressive strength, chloride ion penetration, and water permeability tests) and residual strength after crack repair. The test results show that the use of lightweight aggregate as a carrier and the implantation of Sporosarcina pasteurii can induce biomineralization, strengthen the ITZ, and repair small internal cracks in concrete, thereby improving the strength and durability of the concrete.
\end{abstract}

Keywords: biomineralization; durability; self-healing concrete; crack repair

\section{Introduction}

Concrete is a composite material that is constituted by its basic elements. Due to its excellent properties and relatively cheap cost, concrete has become the most commonly used building material in the world. In essence, durable concrete will retain its original form, quality, and serviceability when exposed to the environment [1]. However, deformations in concrete occur as a result of the material's response to external loads and the environment [2]. These deformations often lead to cracking. The resulting cracks can reduce the durability of concrete structures. Therefore, the issue of how to extend the life of concrete structures has been the focus of research by experts in the concrete field in various countries around the world.

The factors that cause cracking of concrete can be roughly divided into internal causes, such as alkali aggregate reactions, and external causes, such as physical, chemical, and mechanical effects [2]. Depending on the factors responsible for the formation of concrete cracks, many different repair methods have been developed. However, most of the materials currently used for concrete crack repair are epoxy 
systems, acrylic resins, or silicone-based polymers [3,4]. With the increase in environmental protection awareness, these environmentally unfriendly repair materials must be eliminated. In addition, the repair effect of these substances is not very significant due to compatibility issues with the concrete substrate, so researchers from various countries have been working toward environmentally friendly and sustainable repair of biological systems [5-22].

Many studies have pointed out that small cracks in concrete can be repaired by themselves based on the continuous hydration of cement or other physical and mechanical behaviors $[5,6,10,11,13,14]$. In the field of concrete science, this phenomenon is often called "autogenous healing" or "concrete self-healing." Biomineralization is an effect that occurs widely in nature and is defined as the process by which organisms produce minerals through metabolic activities related to interaction with the environment [13]. In biomineralization, living organisms produce biomineral phases with biopolymers [20]. The microorganisms involved secrete one or more metabolites that react with ions or compounds in the environment, resulting in the subsequent deposition of mineral particles as metabolites [23]. Biomineralization is significantly different from geological mineralization because the crystallization of the inorganic phase is strictly controlled by the organic matter secreted by the organism [24]. Therefore, biomineralization can often form an ordered natural organic-inorganic composite material with excellent structure. In view of this, in recent years, microbiologically induced calcium carbonate precipitation (MICP) technology based on microbial mineralization has become a hot topic in concrete self-healing technology and has attracted widespread attention in the academic community [5-23].

In biomineralization, the most commonly used strain is Sporosarcina pasteurii (formerly Bacillus pasteurii) [25]. It is a Gram-positive bacterium commonly found in soil and produces a large amount of intracellular urease. These ureases can catalyze the hydrolysis of urea to produce carbon dioxide, ammonia, and hydroxide ions. With the release of hydroxide ions, the $\mathrm{pH}$ gradually rises, and carbon dioxide is converted into carbonate ions, which combine with calcium ions in the environment to form calcium carbonate precipitates or gel with other substances [26,27]. Therefore, the use of Sporosarcina pasteurii for MICP has been extensively studied [25-30]. In fact, the main behavior of MICP is calcium carbonate precipitation. As far as concrete is concerned, most scholars believe that calcium carbonate precipitation is the most important factor affecting the autogenous healing of concrete. MICP technology uses urease secreted during microbial metabolism to hydrolyze urea in order to generate carbonate ions, which combine with calcium ions to form calcium carbonate with high-quality cementation, thereby achieving the purpose of improving the mechanical properties of concrete [26-30]. Compared with traditional repair methods, MICP technology has obvious advantages such as eco-environmental protection, economic efficiency, and so on. In view of this, many scholars have carried out extensive research to discuss MICP technology and its application.

Many published studies have confirmed that calcium carbonate precipitates produced by bacteria have been successfully used to repair concrete or limestone surfaces, and that they significantly increase the strength or durability of concrete $[6-8,10-12,15,16]$. However, in essence, the bacteria in these studies were applied externally to cracked concrete structures or specimens. Strictly speaking, the repair mechanisms in these studies cannot meet the definition of self-healing. In view of this, scholars have recently tried to mix bacterial spores and organic compounds required for metabolism with fresh cement paste [30-32]. In these studies, calcium carbonate precipitation from bacteria was clearly observed, but only in early concrete specimens (days 1-7). It is speculated that due to the continuous hydration of concrete, the colloidal pores gradually shrink, causing bacterial cells or spores to be crushed and destroyed during the cement hydration stage [30-32]. Therefore, most scholars agree that a carrier with a "shell" function is needed to protect the added bacteria, so that the bacteria can remain active and mineralize to produce carbonate precipitation without negatively affecting the concrete matrix.

At the macroscopic level, concrete may be considered to be a two-phase material, consisting of aggregate particles dispersed in the matrix of the cement paste. However, the interfacial transition 
zone (ITZ) between aggregate and bulk paste constitutes the weakest link in the concrete matrix and significantly affects the performance of concrete [2]. The structure of the ITZ is different from bulk cement paste. The transition zone consists of two layers. One is a composite film with a thickness of about $1 \mu \mathrm{m}$ on the surface of the coarse aggregate, which is mainly composed of calcium hydroxide $(\mathrm{CH})$ crystals and calcium silicate hydrates (C-S-H) colloid; the other is a porous transition zone with a thickness of about 10 to $40 \mu \mathrm{m}$ [33]. Generally, the ITZ is weaker than pastes or aggregates due to the local high water-binder ratio and "wall effect" [2]. In some cases, large crystals of calcium hydroxide and ettringite are mainly oriented perpendicular to the surface of the aggregate. The ITZ in concrete is a weak area with poor strength, which is easy to break under stress and is not conducive to its durability. Therefore, when evaluating the macroscopic nature of concrete, special consideration must be given to the impact of the ITZ. However, the ITZ in concrete is full of $\mathrm{CH}$, which can provide the calcium source required for biomineralization. In other words, the ITZ should facilitate the mineralization reaction.

In view of the above, the purpose of this research is to strengthen the ITZ in concrete and repair concrete cracks by using biological activities that exist in nature, that is, biomineralization technology, to improve the strength and durability of concrete.

\section{Experimental Details}

\subsection{Test Program}

In this study, the bacterial strain Sporosarcina pasteurii, which is environmentally friendly, was selected. In addition, lightweight aggregate was used as a bacterial carrier. The bacteria were first sporulated. To protect the strains, the biological species were fixed in porous lightweight aggregates and then added to the concrete. In this way, on the one hand, the porous lightweight aggregate is used as an aggregate in the concrete, and on the other hand, it is also used as a protective container for bacterial spores. Such a system can improve the feasibility and success rate of bacterial mineralization in concrete.

The planned tests included concrete engineering properties and residual strength after crack repair. Engineering property tests included compressive strength, chloride ion penetration, and water permeability tests to understand whether lightweight aggregate concrete can significantly strengthen its ITZ, reduce its permeability, and thereby increase the strength of the concrete after implantation of bacteria. As for the residual strength test after crack repair, the purpose of this was to understand the crack repair effect of lightweight aggregate concrete implanted with bacteria.

\subsection{Materials}

The materials used in this study included cement, water, fine aggregate, lightweight aggregate, Sporosarcina pasteurii (DSM 33), calcium lactate, yeast extract, calcium acetate, and urea. The cement was locally produced Class I Portland cement with a density of $3.15 \mathrm{~g} / \mathrm{cm}^{3}$ and a fineness of $3400 \mathrm{~cm}^{2} / \mathrm{g}$. The water was ordinary tap water. The fine aggregate was natural sand with a particle size of less than $1 \mathrm{~mm}$. The lightweight aggregate used was crushed from natural shale and fired at a temperature of $1100-1200^{\circ} \mathrm{C}$. As shown in Figure 1, the surface is porous and irregular in shape, with a particle size of 1-8 $\mathrm{mm}$. The basic properties of the artificial lightweight aggregate are shown in Table 1. Sporosarcina pasteurii (DSM 33), whose strain number is BCRC11596, was ordered from the Taiwan Food Industry Development Institute. Calcium lactate was implanted in lightweight aggregates as a nutritional source for Sporosarcina pasteurii. Yeast extract was used, which is powdery, contains a variety of vitamins, minerals, amino acids, etc., and is widely used as a nutrient. Calcium acetate was used as a source of calcium ions in the curing process. Urea was used as a source of carbonate ions during curing. 


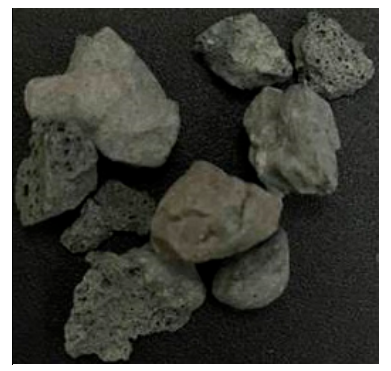

Figure 1. The appearance of lightweight expanded shale aggregates.

Table 1. Basic properties of the lightweight aggregate.

\begin{tabular}{|c|c|c|c|c|c|}
\hline \multirow{2}{*}{$\begin{array}{l}\text { Particle Density } \\
\qquad\left(\mathrm{g} / \mathrm{cm}^{3}\right)\end{array}$} & \multicolumn{2}{|c|}{ Water Absorption (\%) } & \multirow{2}{*}{$\begin{array}{l}\text { Loose Unit Weight } \\
\left(\mathrm{kg} / \mathrm{m}^{3}\right)\end{array}$} & \multirow{2}{*}{$\begin{array}{l}\text { Crushing Strength } \\
\text { (MPa) }\end{array}$} & \multirow{2}{*}{$\begin{array}{c}\text { Porosity } \\
(\%)\end{array}$} \\
\hline & 1-h & 24-h & & & \\
\hline 0.99 & 5.28 & 7.35 & 477.86 & $>3$ & 24.97 \\
\hline
\end{tabular}

\subsection{Strain Implantation}

Two groups of concrete were prepared in this study, one for the control group and the other for the experimental group. The lightweight aggregates of the control group were not implanted with biological species, while the lightweight aggregates of the experimental group were implanted with biological species. The steps to implant the strain into lightweight aggregates were as follows:

(1) Immerse the treated lightweight aggregates in a nutrient source containing $80 \mathrm{~g} / \mathrm{L}$ of calcium lactate and $1 \mathrm{~g} / \mathrm{L}$ of yeast extract for $30 \mathrm{~min}$.

(2) After soaking, drain the moisture from the lightweight aggregates and place them in an oven at $37^{\circ} \mathrm{C}$ for 5 days.

(3) Repeat steps (1) and (2) once, and then immerse the lightweight aggregates into the nutrient source twice.

(4) Dip the lightweight aggregates containing the nutrition source into the bacterial spore solution for $30 \mathrm{~min}$.

(5) Drain the soaked lightweight aggregates and place them in an oven at $37^{\circ} \mathrm{C}$ for 5 days to complete the implantation of the strains in the lightweight aggregates.

\subsection{Mix Proportions}

After the strains were implanted into the lightweight aggregate, concrete mixing was carried out. The water-to-cement ratio of the mixed concrete was 0.60 , and the detailed proportioning design is shown in Table 2. Once the concrete was mixed, 33 cylindrical specimens $(100 \mathrm{~mm}$ in diameter $\times$ $200 \mathrm{~mm}$ in height) and 18 cylindrical specimens ( $150 \mathrm{~mm}$ in diameter $\times 300 \mathrm{~mm}$ in height) were cast and compacted using an external vibrator. Cylindrical specimens with a diameter of $100 \mathrm{~mm}$ and a height of $200 \mathrm{~mm}$ were used for the compressive strength and chloride ion penetration tests of the biomineralized concrete. Cylindrical specimens with a diameter of $150 \mathrm{~mm}$ and a height of $300 \mathrm{~mm}$ were used for the residual strength and water permeability tests after biomineralization repair. After casting, all the specimens were covered overnight with wet hessian and polyethylene sheets for a period of $24 \mathrm{~h}$. After $24 \mathrm{~h}$, the specimens were demolded.

Table 2. Mix proportions of concrete.

\begin{tabular}{cccccc}
\hline Mix No. & W/C & Water $\left(\mathbf{k g} / \mathbf{m}^{3}\right)$ & Cement $\left(\mathbf{k g} / \mathbf{m}^{3}\right)$ & Lightweight Aggregate $\left(\mathbf{k g} / \mathrm{m}^{3}\right)$ & Sand $\left(\mathbf{k g} / \mathbf{m}^{3}\right)$ \\
\hline LC & 0.60 & 240 & 400 & 399 & 524 \\
\hline
\end{tabular}

Notes: $\mathrm{LC}=$ lightweight aggregate concrete; $\mathrm{W} / \mathrm{C}=$ water-to-cement ratio. 


\subsection{Curing Methods}

The specimens of the control group were lightweight aggregate concrete without implanted bacteria or a nutrient source. The curing method was to place the specimens directly in the curing room for air curing. The temperature of the curing room was maintained at $23 \pm 1.5^{\circ} \mathrm{C}$, and the humidity was $100 \%$. According to the different curing methods, the experimental group of concrete specimens was divided into experimental group I and experimental group II. Among these groups, the air-cured concrete specimens were regarded as experimental group I, and the cycle-cured concrete specimens were regarded as experimental group II. The specimens in experimental group I were implanted with bacteria and a nutrient source. The curing method was the same as that of the control group. The specimens in experimental group II were immersed in a mixed aqueous solution of urea and calcium acetate, wherein the mixed aqueous solution contained urea at a concentration of 1 mole and calcium acetate at a concentration of 0.5 moles. The bacteria implanted into the lightweight aggregate are aerobic bacteria. If the specimen is continuously immersed in the aqueous solution, the strain will not be able to operate due to hypoxia and so it will still be dormant. Therefore, the specimens were alternated between curing in a mixed aqueous solution and air. That is to say, the specimens were immersed in an aqueous solution for 1 day, and then the specimens were taken out and placed in the air for 1 day, and the cycle number was 2 days until the required age, at which point they were taken out and observed. All specimens were cured until the day before the test age. After the specimens were taken out of the curing tank, they were kept in a dry state, and various tests were carried out to verify the self-healing effect of the concrete.

\subsection{Test Methods}

The compressive strength test was performed in accordance with the Chinese National Standards CNS 1232 test method [34], and loading was performed at a rate of $588 \mathrm{~N} / \mathrm{s}$ until the test specimen was broken. After this, the concrete of the control group and the experimental group was made into a cylinder with a diameter of $10 \mathrm{~cm}$ and a height of $20 \mathrm{~cm}$, and then cured to the planned age. The specimen was then sawn into a circular cake with a diameter of $10 \mathrm{~cm}$ and a thickness of $5 \mathrm{~cm}$ for a chloride ion penetration test. The $5 \mathrm{~cm}$ thickness of each circular cake was taken from the body of the cylinder starting at $6 \mathrm{~cm}$ from the bottom. The chloride ion penetration test is based on the CNS 14795 test method [35]. It mainly measures the current passing through a cylindrical specimen with a thickness of $51 \mathrm{~mm}$ and a nominal diameter of $102 \mathrm{~mm}$ during a $6 \mathrm{~h}$ test period. The water permeability test was performed under a pressure of $0.29 \mathrm{MPa}$ for $1 \mathrm{~h}$. After the test, the specimen was split to observe the water permeability traces instead of water permeability. The equipment related to the chloride ion penetration test and the water permeability test is shown in Figure 2.

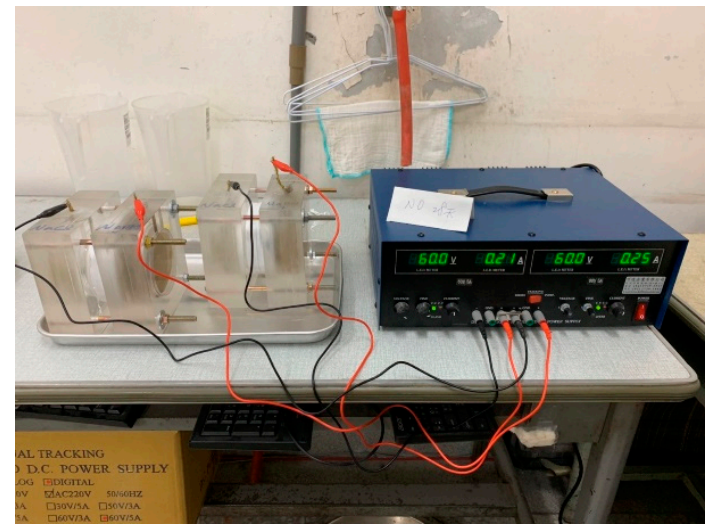

(a)

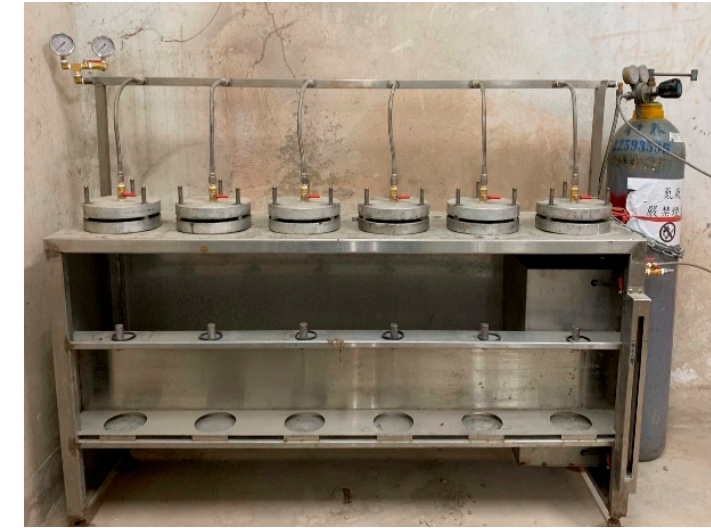

(b)

Figure 2. Test equipment: (a) chloride ion penetration test; (b) water permeability test. 


\section{Results and Discussion}

\subsection{Sporosarcina pasteurii Strain Sporulation and Reactivation Confirmation Test}

In this study, Sporosarcina pasteurii was first treated to a spore state by means of temperature increase. Then, field emission scanning electron microscopy (FE-SEM) observations and spore staining tests were used to verify whether sporulation occurred. After the spore-treated strains were placed in the lightweight aggregate, the spore-forming strains were reactivated to restore their activity for subsequent concrete crack repair testing. Moreover, an XRD test confirmed that the repair material was a bacterial product. For more details, please refer to another published article by the authors [36].

\subsection{Test Results of Compressive Strength of Biomineralized Concrete}

In order to understand the effect of lightweight aggregates implanted with biological strains on the ITZ and strength of concrete, compressive strength tests were performed in accordance with CNS 1232 [34]. The compressive strength of the concrete was evaluated using cylindrical specimens (100 $\mathrm{mm}$ in diameter $\times 200 \mathrm{~mm}$ in height). The strength of the control group and experimental group I at different ages (i.e., 7, 28, 56, and 91 days) was tested. The measured compressive strengths of each group of concrete at different ages are listed in Table 3, which shows the average of three specimens. It can be seen from Figure 3 that as the age increased, the strength of both the control group and experimental group I showed an increasing trend. It can also be seen in Table 3 that the strength at each age of experimental group I was about $6.7 \%-32.8 \%$ higher than that of the control group. This result is similar to that of Balam et al. [37]. The results of the experiments by Balam et al. showed that at ages higher than 28 days and when bacteria were used in lightweight aggregate concrete, the growth of relative compressive strength of concrete increased; it came up to $21.5 \%$ and $26.4 \%$ at ages of 90 days and 150 days, respectively [37]. In addition, it can be clearly seen from Figure 3 that the early strength of experimental group I was higher than that of the control group. As the age increased, the strength of experimental group I and the control group slowed down. Although the strength of the control group increased to become similar to experimental group I, it was not greater than experimental group I.

Table 3. Results and comparison of concrete compressive strength tests.

\begin{tabular}{|c|c|c|c|c|c|c|c|c|}
\hline \multirow{3}{*}{ Group } & \multicolumn{8}{|c|}{ Compressive Strength (MPa) } \\
\hline & \multicolumn{2}{|c|}{7 Days } & \multicolumn{2}{|c|}{28 Days } & \multicolumn{2}{|c|}{56 Days } & \multicolumn{2}{|c|}{91 Days } \\
\hline & $\begin{array}{l}\text { Individual } \\
\text { Value }\end{array}$ & $\begin{array}{l}\text { Average } \\
\text { Value }\end{array}$ & $\begin{array}{l}\text { Individual } \\
\text { Value }\end{array}$ & $\begin{array}{l}\text { Average } \\
\text { Value }\end{array}$ & $\begin{array}{l}\text { Individual } \\
\text { Value }\end{array}$ & $\begin{array}{l}\text { Average } \\
\text { Value }\end{array}$ & $\begin{array}{l}\text { Individual } \\
\text { Value }\end{array}$ & $\begin{array}{c}\text { Average } \\
\text { Value }\end{array}$ \\
\hline \multirow{3}{*}{$\begin{array}{l}\text { Control } \\
\text { Group }\end{array}$} & 18.89 & \multirow{3}{*}{19.04} & 26.43 & \multirow{3}{*}{26.89} & 31.76 & \multirow{3}{*}{31.10} & 31.42 & \multirow{3}{*}{31.20} \\
\hline & 19.09 & & 26.75 & & 30.53 & & 31.19 & \\
\hline & 19.14 & & 27.49 & & 31.01 & & 31.03 & \\
\hline \multirow{3}{*}{$\begin{array}{l}\text { Experimental } \\
\text { Group I }\end{array}$} & 25.34 & \multirow{3}{*}{25.28} & 29.64 & \multirow{3}{*}{29.15} & 33.63 & \multirow{3}{*}{33.18} & 33.76 & \multirow{3}{*}{33.92} \\
\hline & 25.69 & & 29.50 & & 32.40 & & 34.12 & \\
\hline & 24.87 & & 28.31 & & 33.52 & & 33.89 & \\
\hline
\end{tabular}

The strength test results show that the early compressive strength of experimental group I was higher than that of the control group. This should be because of the carbonate ion formed by Sporosarcina pasteurii reacting with some cement hydration products (such as calcium hydroxide) to generate calcium carbonate precipitation, which then filled the ITZ on the surface of the lightweight aggregate (see Figure 4) and the tiny pores in the concrete. As a result, the early compressive strength of the concrete was higher than that of the control group. This result is consistent with the study by Harikrishnan et al. [38]. 


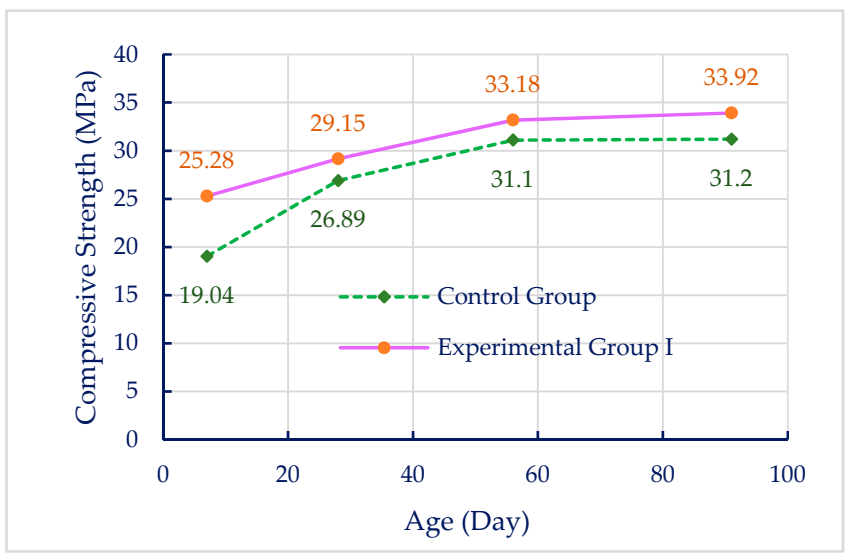

Figure 3. Comparison of compressive strength between biomineralized concrete and control group concrete.

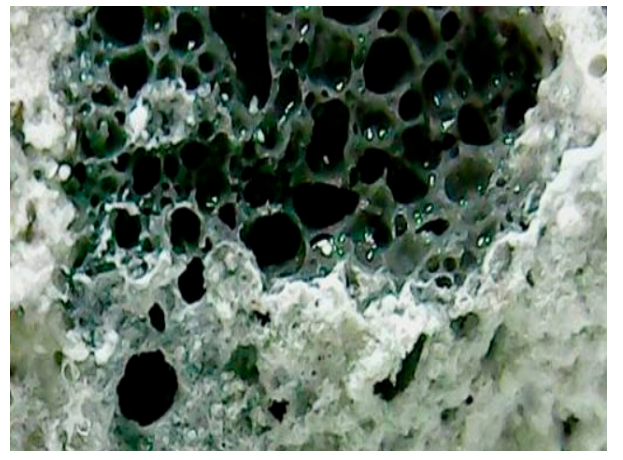

Figure 4. Interfacial transition zone (ITZ) observation of experimental group I under a portable microscope (500 times magnification).

In the later period, the strength growth of experimental group I slowed down. The possible reason is speculated to be because the completeness of the hydration reaction of the cement made the matrix denser, the pores smaller, and the amount of internal oxygen insufficient, resulting in a decrease in the activity of Sporosarcina pasteurii and a poor mineralization reaction. This resulted in a decrease in the amount of calcium carbonate produced and a reduction in the repair effect, so the strength growth tended to slow down. In the control group without biological strains, the hydration reaction tended to be complete (about $70 \%$ to $80 \%$ ) after 56 days of age. The complete hydration reaction can make the concrete denser, so the strength can rise steadily and approach the strength level of experimental group I.

\subsection{Results of Water Permeability and Residual Strength Tests after Biomineralization Repair}

In this study, cylindrical specimens $(15 \mathrm{~cm}$ in diameter and $30 \mathrm{~cm}$ in height) that were cured in the air for 28 days were used to perform a compression test to create cracks. When the compressive strength reached the ultimate load and then decreased by $981 \mathrm{~N}$, the load was quickly decompressed to prevent the specimens from being broken. Then, according to the individual curing methods of the control group, experimental group I, and experimental group II, the unbroken specimens (with internal microcracks) were cured for another 28 days. After that, at the age of 56 days, the water permeability test was performed first, and then the second compressive strength test was performed to test the specimen's residual compressive strength.

The average depth of water permeation in the longitudinal section of a cylindrical specimen is discussed. For the area where water permeation occurred, it is divided into five equal subareas, and then the penetration depth at the center of each subarea is measured, as shown in Table 4. On the other 
hand, it can be seen from Figure 5 that the permeation depth of the control group at the age of 56 days was significantly deeper than that of experimental group I and experimental group II, and the naked eye can clearly see that the control group had a larger permeation area.

Table 4. Average permeation depth and total permeation area of concrete.

\begin{tabular}{ccccccccc}
\hline Group & $\begin{array}{c}\text { Point 1 } \\
(\mathbf{m m})\end{array}$ & $\begin{array}{c}\text { Point 2 } \\
(\mathbf{m m})\end{array}$ & $\begin{array}{c}\text { Point 3 } \\
(\mathbf{m m})\end{array}$ & $\begin{array}{c}\text { Point 4 } \\
(\mathbf{m m})\end{array}$ & $\begin{array}{c}\text { Point 5 } \\
(\mathbf{m m})\end{array}$ & $\begin{array}{c}\text { Average } \\
\text { Permeation } \\
\text { Depth }(\mathbf{m m})\end{array}$ & $\begin{array}{c}\text { Permeable } \\
\text { Section } \\
\text { Width }(\mathbf{m m})\end{array}$ & $\begin{array}{c}\text { Total } \\
\text { Permeation } \\
\text { Area }\left(\mathbf{m m}^{2}\right)\end{array}$ \\
\hline $\begin{array}{c}\text { Control } \\
\text { Group }\end{array}$ & 30 & 36 & 38 & 35 & 30 & 34 & 142 & 4828 \\
\hline $\begin{array}{c}\text { Experimental } \\
\text { Group I }\end{array}$ & 16 & 23 & 25 & 20 & 15 & 20 & 82 & 1640 \\
\hline $\begin{array}{c}\text { Experimental } \\
\text { Group II }\end{array}$ & 8 & 8 & 8 & 16 & 25 & 13 & 150 & 1950 \\
\hline
\end{tabular}

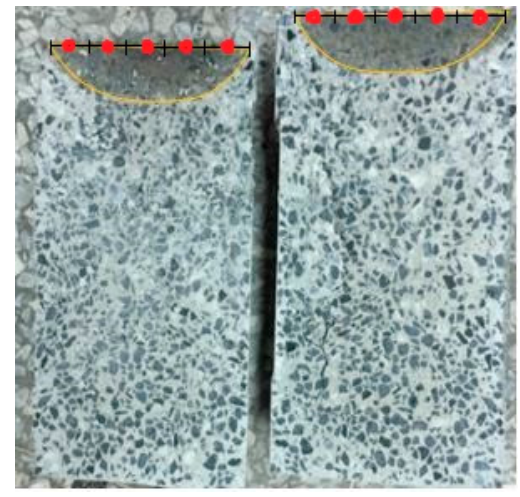

(a)

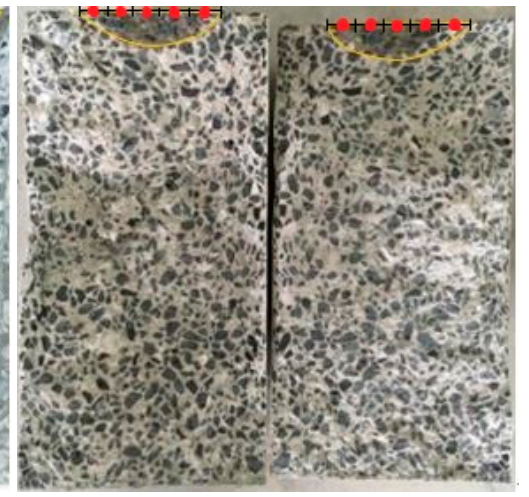

(b)

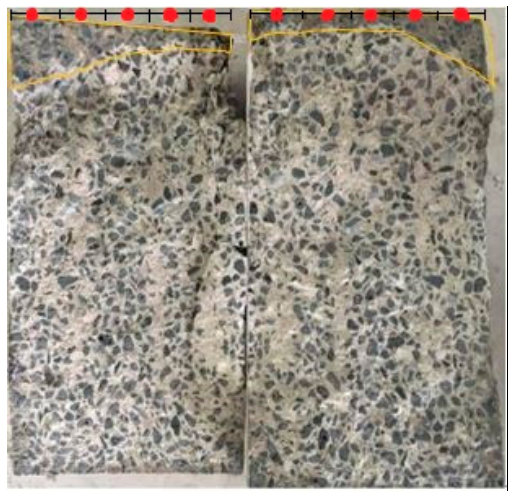

(c)

Figure 5. Traces of water permeability: (a) control group; (b) experimental group I; (c) experimental group II.

As can be seen from Table 4, the average permeation depths of the control group, experimental group I, and experimental group II were 34, 20, and $13 \mathrm{~mm}$, respectively. The results show that, regardless of the curing method, the cracked concrete specimens containing biological bacteria can reduce the water penetration depth in concrete. This result is consistent with the study by Balam et al. [37]. This should be because of the calcium carbonate produced by mineralization in the cracks of the concrete repairing and even strengthening the ITZ on the surface of the aggregate. As a result, the compactness of the concrete was better, and the water permeability of the specimen was reduced. In terms of total permeation area, experimental group II was larger than experimental group I, but compared with the control group, the experimental group with biomineralization had a total permeation area of only about one-third of the control group. This result shows again that biomineralization technology can strengthen the ITZ in concrete and repair concrete cracks to improve the durability of concrete.

The comparison between the original strength measured in the first compressive strength test after 28 days of curing and the residual strength measured in the second compressive strength test after 28 days of curing (age 56 days) after making cracks is shown in Table 5. As can be seen from Figure 6, in terms of the original strength of the specimens at the age of 28 days, the strength of experimental group I was increased by $15 \%$ compared with the control group, and the strength of experimental group II was increased by $17 \%$ compared with the control group. This result shows that the biomineralization technology can indeed increase the strength of concrete. 
Table 5. Comparison of concrete strengths before and after biomineralization.

\begin{tabular}{ccccc}
\hline \multirow{2}{*}{ Group } & \multicolumn{2}{c}{ Original Strength at 28 Days (MPa) } & \multicolumn{2}{c}{ Residual Strength at 56 Days (MPa) } \\
\cline { 2 - 5 } & Individual Value & Average Value & Individual Value & Average Value \\
\hline \multirow{2}{*}{ Control Group } & 26.19 & & 21.09 & 21.97 \\
& 25.51 & 26.00 & 19.72 & 25.41 \\
Experimental Group I & 26.29 & & 25.51 & 27.30 \\
& 29.92 & \multirow{2}{*}{29.96} & 25.40 & 27.32 \\
\hline \multirow{2}{*}{ Experimental Group II } & 29.82 & & 27.81 & 2.78 \\
\hline
\end{tabular}

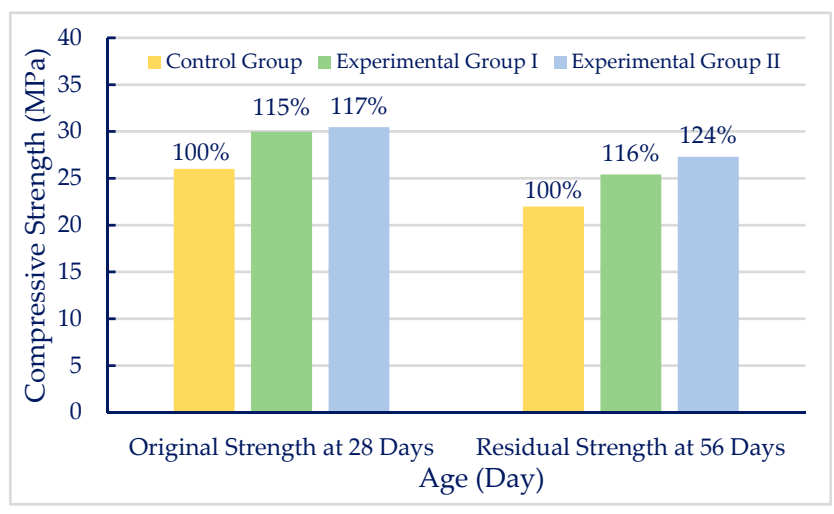

Figure 6. Comparison of concrete strengths.

From the results of the residual compressive strength in Table 5, it can be seen that regardless of whether it is the control group, experimental group I, or experimental group II, after the ultimate bearing capacity, the 56 day residual compressive strength could not be restored to its original strength at the age of 28 days despite the different curing methods. It can be seen from Table 5 that the 56 day residual compressive strength of the control group, experimental group I, and experimental group II was reduced by about $15 \%, 15 \%$, and $10 \%$, respectively, compared to the original strength at the age of 28 days. In addition, as can be seen from Figure 6, the residual compressive strength of experimental group I after mineralization was $16 \%$ higher than that of the control group, and the residual compressive strength of experimental group II was $24 \%$ higher than that of the control group. This result once again proves that biomineralization technology can strengthen the ITZ in concrete or repair concrete cracks and improve the strength of concrete.

From the results of the above compressive strength test, it can be seen that after the lightweight aggregate concrete containing biological bacteria was damaged, whether it was subjected to air curing or cyclic curing, the residual strength decreased less than it did in the control group. The residual strength of experimental group II was even greater than the original strength of the control group at the age of 28 days. It is speculated that the sufficient calcium source in the external environment can lead to a full biomineralization reaction to repair the cracks caused by the damage and thus maintain the residual strength of the concrete.

\subsection{Test Results of Chloride Ion Penetration of Biomineralized Concrete}

The chloride ion penetration test also helps to understand whether the implantation of biological bacteria in lightweight aggregates can affect the compactness of concrete. The test results are shown in Table 6 . The average electric flux of the control group specimens was 19,043 Coulombs. The average electric flux of experimental group I was 17,312 Coulombs, which was about $9.1 \%$ lower than that of 
the control group. The average electric flux of experimental group II was 17,157 coulombs, which was about $9.9 \%$ lower than that of the control group. This result is similar to that of Wu et al. [39]. The results of their experiments showed that the chloride ion permeability rate of specimens cultured in bacterial liquids could be reduced by $10.9 \%$ [39]. From these results, it can be inferred that biomineralization can indeed fill the pores in the concrete, causing the current path to be blocked, resulting in lower electric flux than the nonmineralized concrete.

Table 6. Results of the chloride ion penetration test.

\begin{tabular}{ccc}
\hline \multirow{2}{*}{ Group } & \multicolumn{2}{c}{ Electric Flux (Coulombs) } \\
\cline { 2 - 3 } & \multicolumn{1}{c}{ Individual Value } & Average Value \\
\hline \multirow{2}{*}{ Control Group } & 18,867 & 19,043 \\
& 18,717 & \\
Experimental Group I & 19,546 & 17,312 \\
& 18,259 & \\
\hline \multirow{2}{*}{ Experimental Group II } & 17,017 & 17,157 \\
\hline
\end{tabular}

\section{Conclusions}

The development of biomineralization technology will provide the basis for high-quality concrete and ultimately improve the durability of reinforced concrete structures. According to the test results and analysis, the comprehensive conclusions are as follows:

- Biomineralized lightweight aggregate concrete can significantly increase its early strength due to biomineralization, and its 7 day strength was increased by about $33 \%$ compared with the control group. In the later period, as the hydration reaction of the concrete tended to be complete, the matrix became denser, resulting in insufficient oxygen in the concrete. As a result, it was not easy for Sporosarcina pasteurii to operate, which slowed down the growth of the concrete strength.

- The results of water permeability tests show that the permeation depth and total permeation area of lightweight aggregate concrete containing biological bacteria were smaller than those of the control group. This confirms that biomineralization can strengthen the ITZ in concrete and repair concrete cracks, thereby increasing the compactness of concrete and improving its durability.

- The chloride ion test results show that the electric flux of lightweight aggregate concrete containing biological bacteria was lower than that of the control group, indicating that biomineralization can strengthen the ITZ in concrete and repair concrete cracks, thereby improving the durability of concrete.

- The reduction ratio of the residual compressive strength of the biomineralized concrete was lower than that of the control group concrete, indicating that biomineralization can repair the damaged concrete and help it to maintain a certain residual strength. In particular, the residual strength of the experimental group using cyclic curing was even higher than the original strength of the control group. This result shows that biomineralization does have the effect of repairing concrete cracks.

- This study demonstrates that the use of lightweight aggregate as a carrier and the implantation of Sporosarcina pasteurii can induce biomineralization, strengthen the ITZ, and repair small internal cracks in concrete, thereby improving the strength and durability of the concrete.

Author Contributions: Conceptualization, H.-J.C. and C.-W.T.; methodology, H.-J.C.; software, H.-J.C.; validation, H.-J.C., M.-C.C. and C.-W.T.; formal analysis, H.-J.C.; investigation, M.-C.C.; resources, H.-J.C.; data curation, 
M.-C.C.; writing—original draft preparation, H.-J.C.; writing—review and editing, C.-W.T.; visualization, M.-C.C. and C.-W.T.; supervision, H.-J.C.; project administration, H.-J.C.; funding acquisition, H.-J.C. All authors have read and agreed to the published version of the manuscript.

Funding: The research was funded by the Ministry of Science and Technology of Taiwan grant number MOST 108-2221-E-230-003-MY2.

Acknowledgments: The authors sincerely thank the Ministry of Science and Technology of Taiwan for funding this research work.

Conflicts of Interest: The authors declare no conflict of interest.

\section{References}

1. Mindess, S.; Young, J.F.; Darwin, D. Concrete, 2nd ed.; Prentice-Hall: Upper Saddle River, NJ, USA, 2003.

2. Metha, P.K.; Monteiro, P.J.M. Concrete: Microstructure, Properties and Materials, 3rd ed.; McGraw-Hill: New York, NY, USA, 2006.

3. Sierra-Beltran, M.G.; Jonkers, H.M.; Schlangen, E. Characterization of sustainable bio-based mortar for concrete repair. Constr. Build. Mater. 2014, 67, 344-352. [CrossRef]

4. Dry, C.M. Three designs for the internal release of sealants, adhesives, and waterproofing chemicals into concrete to reduce permeability. Cem. Concr. Res. 2000, 30, 1969-1977. [CrossRef]

5. Castro-Alonso, M.J.; Montañez-Hernandez, L.E.; Sanchez-Muñoz, M.A.; Franco, M.R.M.; Narayanasamy, R.; Balagurusamy, N. Microbially Induced Calcium Carbonate Precipitation (MICP) and Its Potential in Bioconcrete: Microbiological and Molecular Concepts. Front. Mater. 2019, 6, 126. [CrossRef]

6. Menon, R.R.; Luo, J.; Chen, X.; Zhou, H.; Liu, Z.; Zhou, G.; Zhang, N.; Jin, C. Screening of fungi for potential application of self-healing concrete. Sci. Rep. 2019, 9, 2075. [CrossRef] [PubMed]

7. Han, S.; Choi, E.K.; Park, W.; Yi, C.; Chung, N. Effectiveness of expanded clay as a bacteria carrier for self-healing concrete. Appl. Biol. Chem. 2019, 62, 19. [CrossRef]

8. Magaji, A.; Yakubu, M.; Wakawa, Y.M. A review paper on self healing concrete. Int. J. Eng. Sci. 2019, 8, 47-54.

9. Sikder, A.; Saha, P. Effect of Bacteria on Performance of Concrete/Mortar: A Review. Int. J. Recent Technol. Eng. 2019, 7, 23.

10. Xu, J.; Wang, X. Self-healing of concrete cracks by use of bacteria-containing low alkali cementitious material. Constr. Build. Mater. 2018, 167,1-14. [CrossRef]

11. Xu, J.; Wang, X.; Zuo, J.; Liu, X. Self-healing of concrete cracks by ceramsite-loaded microorganisms. Adv. Mater. Sci. Eng. 2018, 2018, 1-8. [CrossRef]

12. Tsangouri, E. A decade of research on self-healing concrete. Sustain. Constr. Build. Mater. 2018. [CrossRef]

13. Iheanyichukwu, C.G.; Umar, S.A.; Ekwueme, P.C. A Review on Self-Healing Concrete Using Bacteria. Sustain. Struct. Mater. Int. J. 2018, 1, 12-20.

14. Kadapure, S.A.; Kulkarni, G.S.; Prakash, K.B. Biomineralization technique in self-healing of fly-ash concrete. Sustain. Build. Technol. Urban Dev. 2017, 8, 54-65. [CrossRef]

15. Palin, D.; Wiktor, V.; Jonkers, H.M. A bacteria-based self-healing cementitious composite for application in low-temperature marine environments. Biomimetics 2017, 2, 13. [CrossRef] [PubMed]

16. Souradeep, G.; Dai, P.S.; Wei, K.H. Autonomous healing in concrete by bio-based healing agents-A review. Constr. Build. Mater. 2017, 146, 419-428.

17. Feiteira, J.; Tsangouri, E.; Gruyaert, E.; Lors, C.; Louis, G.; De Belie, N. Monitoring crack movement in polymer-based self-healing concrete through digital image correlation, acoustic emission analysis and SEM in-situ loading. Mater. Des. 2017, 115, 238-246. [CrossRef]

18. Lee, J.C.; Lee, C.J.; Chun, W.Y.; Kim, W.J.; Chung, C.W. Effect of Microorganism Sporosarcina pasteurii on the Hydration of Cement Paste. J. Microbiol. Biotechnol. 2015, 25, 1328-1338. [CrossRef]

19. Gao, L.; Sun, G. Development of microbial technique in self-healing of concrete cracks. J. Chin. Ceram. Soc. 2013, 41, 627-636.

20. Chen, P.Y.; McKittrick, J.; Meyers, M.A. Biological materials: Functional adaptations and bioinspired designs. Prog. Mater. Sci. 2012, 57, 1492-1704. [CrossRef]

21. Edvardsen, C. Water permeability and autogenous healing of cracks in concrete. ACI Mater. J. 1999, 96, 448-454. 
22. Hearn, N. Self-sealing, autogenous healing and continued hydration: What is the difference? Mater. Struct. 1998, 31, 563-567. [CrossRef]

23. Frankel, R.B.; Bazylinski, D.A. Biologically induced mineralization by bacteria. Rev. Mineral. Geochem. 2003, 54, 95-114. [CrossRef]

24. Krampitz, G.; Graser, G. Molecular mechanism of biomineralization in the formation of calcified shells. Angew. Chem. Int. Ed. Engl. 1988, 27, 145-1156. [CrossRef]

25. Minto, J.M.; Tan, Q.; Lunn, R.J.; Mountassir, G.E.; Guo, H.; Cheng, X. 'Microbial mortar'-restoration of degraded marble structures with microbially induced carbonate precipitation. Constr. Build. Mater. 2018, 180, 44-54. [CrossRef]

26. Bang, S.S.; Galinat, J.K.; Ramakrishnan, V. Calcite precipitation induced by polyurethane-immobilized Bacillus pasteurii. Enzym. Microb. Technol. 2001, 28, 404-409. [CrossRef]

27. Bachmeier, K.L.; Williams, A.E.; Warmington, J.R.; Bang, S.S. Urease activity in microbiologically-induced calcite precipitation. J. Biotechnol. 2002, 93, 171-181. [CrossRef]

28. De Muynck, W.; De Belie, N.; Verstraete, W. Microbial carbonate precipitation improves the durability of cementitious materials: A review. Ecol. Eng. 2010, 36, 118-136. [CrossRef]

29. Ramachandran, S.K.; Ramakrishnan, V.; Bang, S.S. Remediation of concrete using micro-organisms. $A C I$ Mater. J. 2001, 98, 3-9.

30. Jonkers, H.M.; Thijssen, A.; Muyzer, G.; Copuroglu, O.; Schlangen, E. Application of bacteria as self-healing agent for the development of sustainable concrete. Ecol. Eng. 2010, 36, 230-235. [CrossRef]

31. Wiktor, V.; Jonkers, H.M. Quantification of crack-healing in novel bacteria-based self-healing concrete. Cem. Concr. Compos. 2011, 33, 763-770. [CrossRef]

32. Bravo da Silva, F; De Belie, N.; Boon, N.; Verstraete, W. Production of non-axenic ureolytic spores for self-healing concrete applications. Constr. Build. Mater. 2015, 93, 1034-1041. [CrossRef]

33. Ollivier, J.P.; Maso, J.C.; Bourdette, B. Interfacial transition zone in concrete. Adv. Cem. Based Mater. 1995, 2, 30-38. [CrossRef]

34. CNS 1232:2002. Method of Test for Compressive Strength of Cylindrical Concrete Specimens; Chinese National Standards, Bureau of Standards, Metrology and Inspection of the Ministry of Economic Affairs: Taipei, Taiwan, 2002.

35. CNS 14795:2004. Method of Test for Electrical Indication of Concrete's Ability to Resist Chloride Ion Penetration; Chinese National Standards, Bureau of Standards, Metrology and Inspection of the Ministry of Economic Affairs: Taipei, Taiwan, 2004.

36. Chen, H.J.; Peng, C.F.; Tang, C.W.; Chen, Y.T. Self-Healing Concrete by Biological Substrate. Materials 2019, 12, 4099. [CrossRef] [PubMed]

37. Balam, N.H.; Mostofinejad, D.; Eftekhar, M. Effects of bacterial remediation on compressive strength, water absorption, and chloride permeability of lightweight aggregate concrete. Constr. Build. Mater. 2017, 145, 107-116. [CrossRef]

38. Harikrishnan, H.; Kadaikunnan, S.; Moorthy, I.G.; Anuf, A.R.; Ponmurugan, K.; Kumar, R.S. Improvement of concrete durability by bacterial carbonate precipitation. South Indian J. Biol. Sci. 2015, 1, 90-96. [CrossRef]

39. Wu, M.; Hu, X.; Zhang, Q.; Xue, D.; Zhao, Y. Growth environment optimization for inducing bacterial mineralization and its application in concrete healing. Constr. Build. Mater. 2019, 209, 631-643. [CrossRef]

(C) 2020 by the authors. Licensee MDPI, Basel, Switzerland. This article is an open access article distributed under the terms and conditions of the Creative Commons Attribution (CC BY) license (http://creativecommons.org/licenses/by/4.0/). 